\title{
Cannulation technique and complications in arteriovenous fistulas: a Swedish Renal Registry-based cohort study
}

Karin Staaf ${ }^{1 *}$, Anders Fernström ${ }^{1}$ and Fredrik Uhlin ${ }^{1,2}$

\begin{abstract}
Background: The four cannulation techniques, rope ladder (RL), area puncture (AP), buttonhole with blunt needles $(\mathrm{BHb})$, and buttonhole with sharp needles (BHs), affects the arteriovenous fistula (AVF) in different ways. The aim of this study was to describe the relationship between the different cannulation techniques and the occurrence of AVF complications.

Methods: The study was performed as a national registry-based cohort study using data from the Swedish Renal Registry (SRR). Data were collected from January 2014 to October 2019. Seventy of Sweden's dialysis units participate in the registry. We analyzed a total of 1328 AVFs in this study. The risk of complications was compared between the four different cannulation techniques. The risk of AVF complications was measured by the incidence and incidence rate ratio (IRR). We compared the IRRs of complications between different cannulation techniques.

Results: $\mathrm{BHs}$ is the most common cannulation technique in Sweden. It has been used in 55\% of the AVFs at some point during their functional patency. BHb (29\%), RL (13\%), and AP (3\%) has been used less. BHb had the lowest risk of complications compared to the other techniques, and a significantly lower risk of stenosis, infiltration, cannulation difficulties, compared to RL and BHs. Cannulation difficulties were significantly more common using AP compared to $\mathrm{BHs}$, and $\mathrm{BHb}$. Infections were not significantly increased using the buttonhole technique.

Conclusions: $\mathrm{BHb}$ had the lowest risk of complications. Infections were not significantly increased using the buttonhole technique. Dialysis units with a low infection rate may continue to use the buttonhole technique, as the risk of complications is lower.
\end{abstract}

Keywords: Area puncture, Blunt needle, Buttonhole, Cannulation, Cannulation-related complications, Hemodialysis, Rope ladder, Sharp needle, Vascular access

\section{Introduction}

Individuals with chronic kidney disease (CKD) who require hemodialysis must have functioning access to the blood. There are three ways to create an access: central venous catheter, arteriovenous graft, and arteriovenous fistula (AVF). The AVF is the most common and most

\footnotetext{
* Correspondence: karin.staaf@regionostergotland.se

'Department of Nephrology and Department of Health, Medicine and Caring Sciences, Linköping University, SE-581 85 Linköping, Sweden

Full list of author information is available at the end of the article
}

preferred access because it has the longest patency and fewest complications $[1,2]$. Yet, according to the Dialysis Outcomes and Practice Patterns Study (DOPPS), complications occur in 37\% of all new AVFs over the first 6 months. These complications include local and general infections as well as stenosis and thromboses [3]. When the AVF is established, complications decrease. A European follow-up study reported a complication rate of $15.5 \%$ at 1 year [4].

C C The Author(s). 2021 Open Access This article is licensed under a Creative Commons Attribution 4.0 International License, which permits use, sharing, adaptation, distribution and reproduction in any medium or format, as long as you give appropriate credit to the original author(s) and the source, provide a link to the Creative Commons licence, and indicate if changes were made. The images or other third party material in this article are included in the article's Creative Commons licence, unless indicated otherwise in a credit line to the material. If material is not included in the article's Creative Commons licence and your intended use is not permitted by statutory regulation or exceeds the permitted use, you will need to obtain permission directly from the copyright holder. To view a copy of this licence, visit http://creativecommons.org/licenses/by/4.0/ The Creative Commons Public Domain Dedication waiver (http://creativecommons.org/publicdomain/zero/1.0/) applies to the data made available in this article, unless otherwise stated in a credit line to the data. 
AVF complications have different causes and severity, requiring various treatments and preventative approaches [5]. The most common AVF complications were stenosis, thromboses, bleeding, infection, high pressure, aneurysm, flow problems, and steal syndrome [4]. Complications lead to an increased need of care, are time-consuming for the patient, and increased pain, anxiety, and stress [6].

Vascular anatomy, surgical technique, AVF placement, and previous complications, as well as co-morbidity, sex, and age of both the patient and the AVF, affect AVF maturity, occurrence of complications and patency $[2,7]$. Other factors that affect the AVF is daily care, time to first cannulation, the cannulation technique used, and the size and angle of the needle inserted [8-11].

Guidelines describe three possible ways to cannulate an AVF: rope ladder (RL), area puncture (AP), and buttonhole $(\mathrm{BH})$. When using RL, the cannulator creates a new puncture site each time. The puncture site is placed 0.5 $\mathrm{cm}$ from the last puncture site and the whole length of the AVF is used. Cannulators using AP also create new puncture sites each time, but they place all sites in the same area, rarely larger than $2-3 \mathrm{~cm}$ in diameter. When $\mathrm{BH}$ is used, the needle is placed in exactly the same cannulation tract, using the same angle each time. To create a tunnel tract, sharp needles are used. When the tract is formed, cannulation can be done with blunt needles [5]. Even though blunt needles are most common using $\mathrm{BH}$, sharp needles might be a long time solution [12-14]. Long-time use with sharp needles will therefore be referred to as buttonhole sharp (BHs) and the cannulation technique using blunt needles as buttonhole blunt (BHb). The different cannulation techniques are used to varying extents worldwide. In the US, RL is the most common technique [15], whereas in Europe, AP is most frequently used (66\% vs. RL $30 \%$ and $\mathrm{BH} 6 \%$ ) [9].

The different cannulation techniques have been investigated and, according to both American and European guidelines, AP should not be used $[1,2,5]$ because the risk of complications such as aneurysms and hemorrhage is imminent $[16,17]$. Opinions differ when it comes to RL and BH. Studies have shown that the techniques affect patients in different ways. For example, RL leads to more infiltrations and aneurysms but a reduced risk of infection compared to $\mathrm{BH}$ [18]. Few randomized trials have been conducted, and most of the conclusions have been drawn from observational studies $[2,19]$.

A systematic literature review showed that, compared to RL, BH led to fewer interventions related to thromboses and stenosis. $\mathrm{BH}$ also led to the formation of fewer aneurysms [20]. In contrast, BH cannulation increases the risk of infections [18]. Studies comparing $\mathrm{BHb}$ versus $\mathrm{BHs}$ have not reported any significant difference in the incidence of stenosis [12] or any significant difference regarding infections between the two techniques [12, 14]. However, both everyday complications and bleeding between dialysis were more common with $\mathrm{BHs}$ than $\mathrm{BHb}$ [12].

An optimal cannulation technique remains to be found. Therefore, the outcomes of different cannulation techniques need to be compared in a larger population for a longer period than in previous studies. The population should also include as many dialysis units as possible in order to reduce the effect of local procedures on the outcome. The aim of the present study was to describe the relationship between different AVF cannulation techniques and the occurrence of complications.

\section{Materials and methods Study design}

The study was performed as a national registry-based cohort study using data from the Swedish Renal Registry (SRR). SRR includes all adult patients with CKD stage 4-5 in Sweden. Data are continuously registered, including patients' AVFs and their care. The SRR provides an opportunity to study the entire Swedish hemodialysis population for a long period of time [21]. Registry data were obtained after written approval from the SRR.

\section{Data collection}

Data regarding gender, year of birth, kidney disease, and region were collected for all patients who had a newly created AVF with onset of function during the period 1 January 2014 to 25 October 2019. Data collected regarding AVFs were date of surgery, type, location, functional start (date), cannulation techniques (date range), complications (date), and abandonment (reason and date).

During the period, 4008 individuals with AVFs were registered in the SRR. Patients whose AVFs were abandoned before the first cannulation were excluded, as well as those who lacked a registered cannulation technique (Fig. 1). A total of 2601 AVFs were initially included in the study. Patients in this population had been exposed to one or to several cannulation techniques. After the first analysis the population was reduced to only include patients exposed to a single cannulation technique during patency, i.e. 1328 AVFs. $\mathrm{BHs}$ during 1 to 40 days which preceded $\mathrm{BHb}$ (to create a tunnel track) was considered as $\mathrm{BHb}$. If $\mathrm{BHs}$ was used for longer than 40 days preceding $\mathrm{BHb}, \mathrm{BHs}$ and $\mathrm{BHb}$ were assessed as different techniques. The analysis was based on the included fistulas. The cannulation techniques found in the SRR are $\mathrm{BHb}, \mathrm{BHs}$, $\mathrm{RL}$, and AP. The analyses were based on the incidence of AVF complications in relation to the cannulation technique use. Fistula days were calculated 


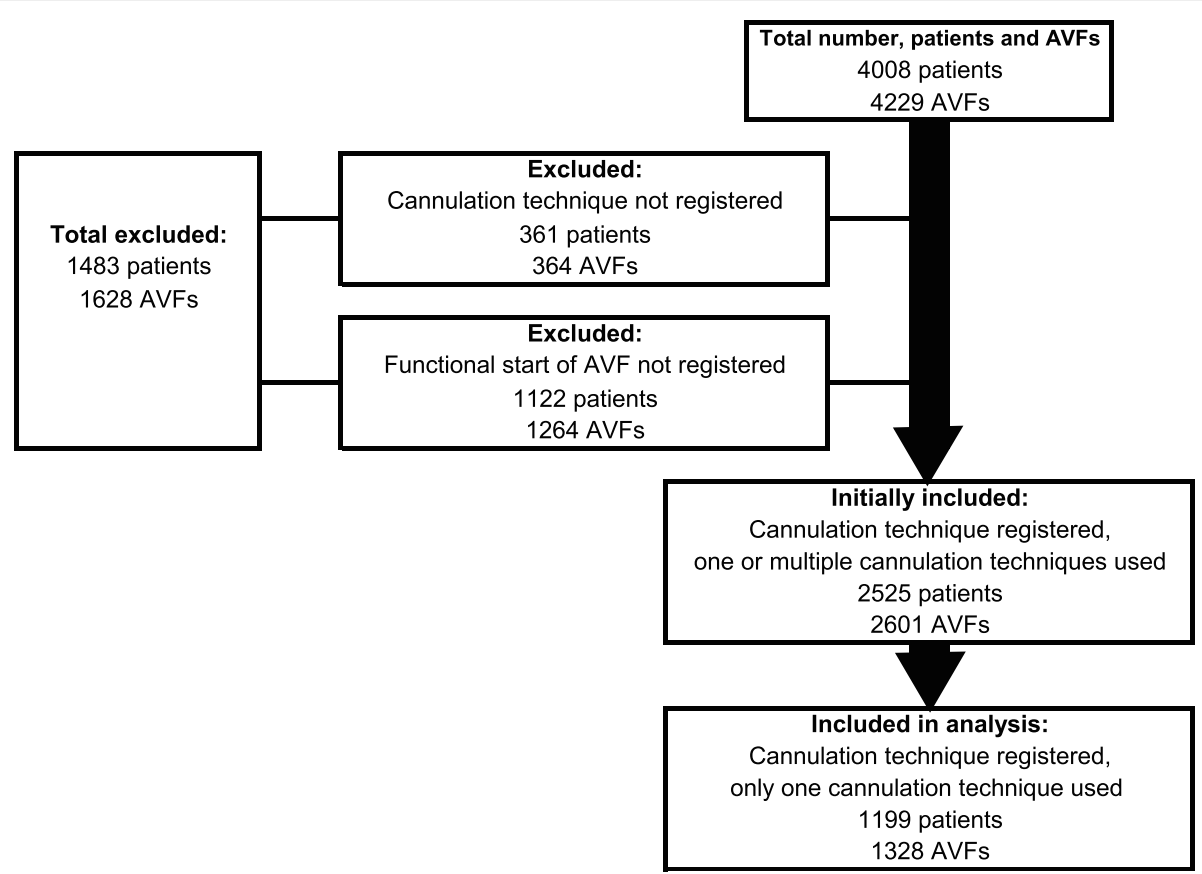

Fig. 1 Flow diagram of patients and AVF inclusion in the study

from the onset of function to AVF abandonment (occlusion/primary occlusion, AVF ligation, patient refuses use, lost to follow-up, non-function, patient deceased) or end of study.

All registered AVF complications were included. To increase comparability with previous studies and reduce the risk of ambiguities regarding the definition of certain complications, such as aneurysm/pseudoaneurysm and different types of infection, they were grouped into broader categories (Table 1). All defined complications, AVF types and reasons for abandonment are taken from the SRR.

Table 1 Definition of complications in the SRR

\begin{tabular}{|c|c|c|}
\hline Complication category & Complication registered in SRR & Definition of complication in SRR \\
\hline Bleeding & Bleeding & $\begin{array}{l}\text { Is registered if it leads to blood transfusion. Reoperation, } \\
\text { hospitalization, or prolonged hospitalization }\end{array}$ \\
\hline Thrombosis/occlusion & Thrombosis/occlusion & That leads to intervention or AVF abandonment \\
\hline Stenosis & $\begin{array}{l}\text { Stenosis vein } \\
\text { Stenosis artery } \\
\text { Stenosis vein }+ \text { vein branches } \\
\text { Stenosis artery + vein }\end{array}$ & $\begin{array}{l}\text { Is registered if it leads to angioplasty or if the velocity is } 2.5 \text {-times } \\
\text { increased measured with duplex ultrasound or }>50 \% \text { reduction in } \\
\text { the diameter measured with venography }\end{array}$ \\
\hline Infection & $\begin{array}{l}\text { Infection } \\
\text { Infection - local } \\
\text { Infection - general }\end{array}$ & $\begin{array}{l}\text { Local or general infection originating in the AVF and needs treatment } \\
\text { with antibiotics }\end{array}$ \\
\hline \multirow[t]{3}{*}{ Other } & $\begin{array}{l}\text { Stenosis central vein } \\
\text { Stenosis central vein }+ \text { other stenosis }\end{array}$ & $\begin{array}{l}\text { The stenosis is called central from the beginning of the vena cephalica } \\
\text { in the vena subclavia or proximal of this point; stenosis in central vein } \\
\text { registered even though it doesn't lead to an intervention }\end{array}$ \\
\hline & $\begin{array}{l}\text { Steal syndrome } \\
\text { Vein branches } \\
\text { Other }\end{array}$ & That leads to intervention or AVF abandonment \\
\hline & $\begin{array}{l}\text { Low flow } \\
\text { High flow }\end{array}$ & That leads to intervention or AVF abandonment \\
\hline Aneurysm & $\begin{array}{l}\text { Pseudoaneurysm } \\
\text { Aneurysm }\end{array}$ & That leads to intervention or AVF abandonment \\
\hline Cannulation difficulty & Cannulation difficulty & That leads to intervention or AVF abandonment \\
\hline Infiltration & Infiltration & That leads to intervention or AVF abandonment \\
\hline
\end{tabular}




\section{Statistical analysis}

Incidence and confidence intervals were calculated for each group using the Poisson 95\% Confidence Interval using number of events and AVF-days. In betweengroup comparisons, the incidence rate ratio (IRR) was used [22]. Adjustments for confounders were made using Mantel-Haenszel stratification. Averages were compared using the t-test and ANOVA. Binary outcomes were compared using the $X^{2}$ test. Due to multiple analyses (six different comparisons) Bonferroni correction was used to correct the statistical significance from $p<0.05$ to $p<0.008$. During binary comparison, statistical significance was set to $p<0.05$. All methods were carried out in accordance with relevant guidelines and regulations.

Microsoft Excel 2010 (Microsoft, USA) was used as a database for collecting and grouping data and calculating the stratification for the Mantel-Haenszel test. Statistical analysis were performed using IBM SPSS Statistics for Windows, version 25 (IBM Corp., Armonk, NY).

\section{Ethical considerations}

The Swedish Ethical Review Authority gave ethical approval (No. 2019-02554) to the study and has waived the need for informed consent.

\section{Results}

The study included 1199 patients and 1328 AVFs (see Fig. 1) that were retrospectively reviewed for 990,405 AVF days. Of the included patients, 29 had two AVFs during the study period. One-third of the group were women, the most common cause of renal failure was diabetes, and the most frequent AVF was radiocephalic fistula. Just over a quarter of the AVFs were located on the patient's right side (Table 2). The most common technique was BHs. It has been used in $55 \%$ of the AVFs. BHb (29\%), RL (13\%), and AP (3\%) were used less. BHb was used for longer periods than both $\mathrm{BHs}$ and RL (Table 3).

We found a difference in the occurrence of complications when comparing cannulation techniques, and differences between the various types of complications. Stenosis is the most common complication for all cannulation techniques and before exposure to needles. When cannulation techniques are compared against each other, $\mathrm{BHb}$ has the lowest risk of complications compared to the other techniques (Fig. 2 and Table 4).

$\mathrm{BHb}$ has a significantly lower risk of stenosis, infiltration and cannulation difficulties, compared to RL and a significantly lower risk of stenosis and cannulation difficulties compared to BHs. Cannulation difficulties are significantly more common with AP than $\mathrm{BHb}$ and BHs. With regard to infections, there was not a significant difference between $\mathrm{BHs}$ and $\mathrm{BHb}$ compared to $\mathrm{RL}$ (Table 4).

No differences were found in the majority of the values when controlling for the confounding factors gender, diabetes, and right-sided AVF (Table S2).

The risk of having a complication was increased, but not significantly, among women and those with rightsided AVF. Patients with diabetes and those older than 70 years had an increased risk of stenosis when using $\mathrm{BHs}$ and $\mathrm{BHb}$. On the other hand, the infection risk was significantly decreased in patients older than 70 years when using BHb (Table S1).

We found a significant difference $(P<0.001)$ between the amount of patients who did not have complications (57.1\%) compared to those who had complications (42.9\%), regardless of cannulation technique. Those who had least one complication were significantly older $(65.2$ compared to 63.5 years of age, $P=0.04$ ). Those who had at least one complication, in the initial group of 2601 AVFs (see Fig. 1), were exposed to significantly more cannulation techniques $(1.8 \pm 1.025)$ compared to those who had no complications $(1.6 \pm 0.83 ; P<0.001)$.

\section{Discussion}

This study indicates that there are disparities in complication frequency between different cannulation techniques. $\mathrm{BHb}$ has the lowest risk of complications compared to BHs, RL, and AP. Registry data from the SRR made it possible to include a large population from 67 different dialysis units in Sweden. This provided us an opportunity to study the relationship between cannulation techniques and complications, but also an opportunity to examine the long-term consequences of the various cannulation techniques. $\mathrm{BHs}$ and $\mathrm{BHb}$ were the most commonly used techniques, followed by RL. AP was not used extensively (3\%) in this population. There are also local variations in both choice of cannulation technique, age and routines that may have affected the result. These variations are both known (Table 3) and unknown (for example needle or bevel direction) as they were not registered in the SRR.

Only 9\% of the 4229 AVFs were excluded because of lack of registered cannulation technique (see Fig. 1). This indicates that registration in the SRR is quite good, which is also confirmed by the registry validations [23, 24]. Thirty percent of AVFs were excluded due to short AVF patency and abandonment before cannulation was started. This can be compared to the numbers of abandoned AVFs from previous studies, with the numbers matching quite well [2].

AVF-related infections are one of the complications that lacked significant differences in prevalence, regardless of cannulation technique. Two systematic literature reviews have examined the frequency of infection related 


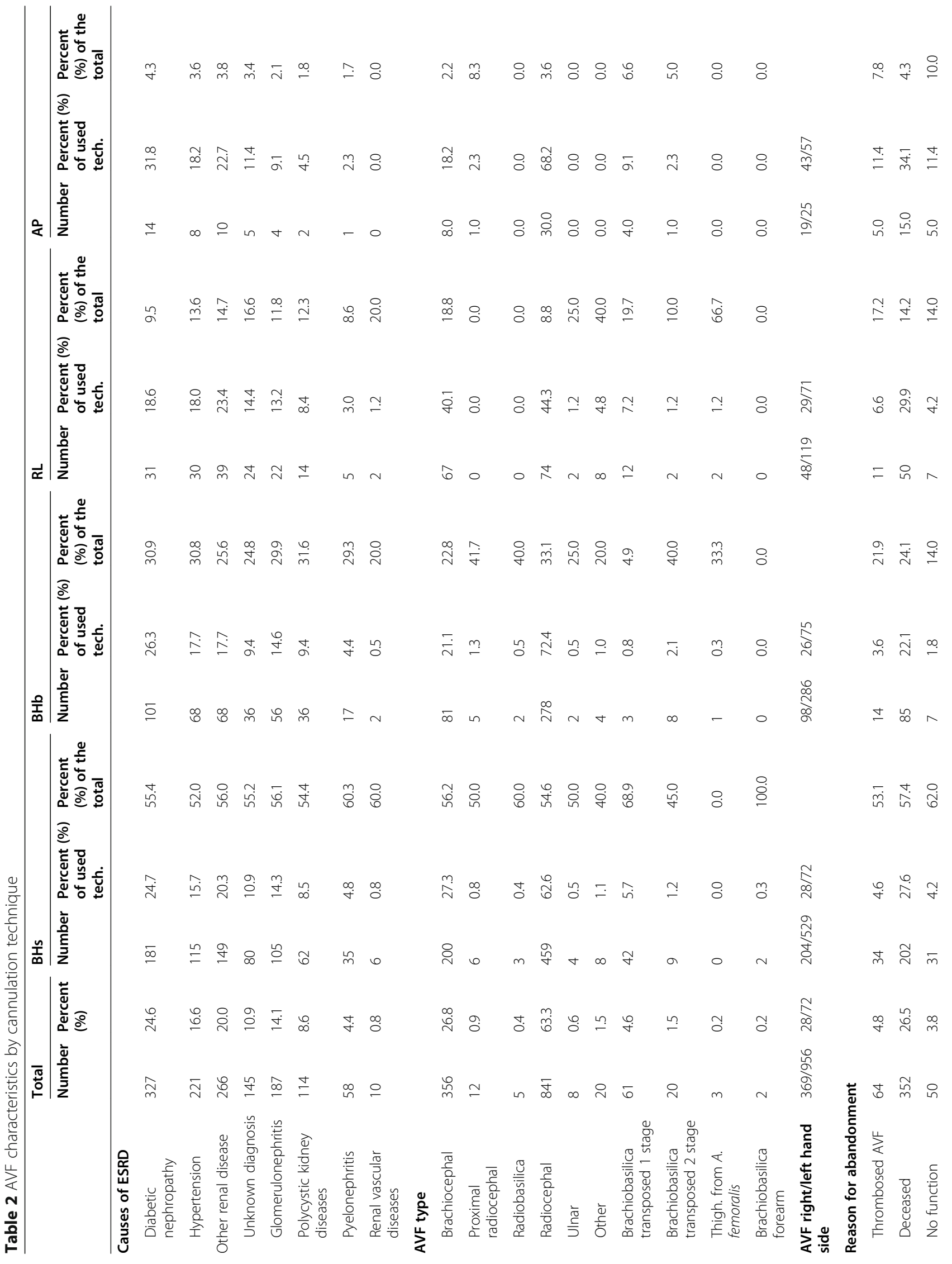




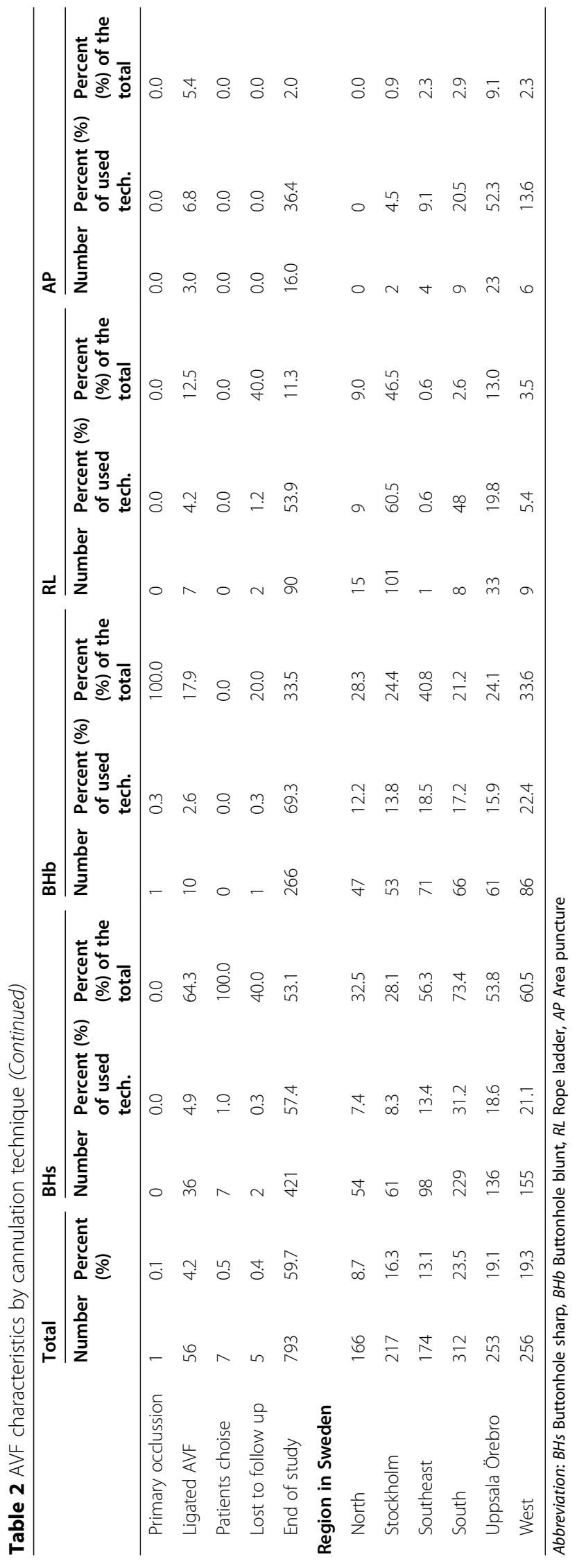


Table 3 AVF characteristics by cannulation technique

\begin{tabular}{|c|c|c|c|c|c|c|c|c|c|c|}
\hline & \multicolumn{2}{|l|}{ Total } & \multicolumn{2}{|l|}{$\mathrm{BHs}$} & \multicolumn{2}{|l|}{$\mathrm{BHb}$} & \multicolumn{2}{|l|}{ RL } & \multicolumn{2}{|l|}{ AP } \\
\hline & Number & Percent & Number & Percent & Number & Percent & Number & Percent & Number & Percent \\
\hline Female/male & $395 / 933$ & $30 / 70$ & $238 / 495$ & $32 / 68$ & $86 / 298$ & $22 / 78$ & $49 / 118$ & 29/71 & $22 / 22$ & $50 / 50$ \\
\hline Age (mean. \pm SD) & $\begin{array}{l}64.3( \pm \\
14.9)\end{array}$ & & $\begin{array}{l}65.0( \pm \\
14.8)\end{array}$ & & $\begin{array}{l}61.3( \pm \\
15.6)\end{array}$ & & $\begin{array}{l}67.6( \pm \\
15.1)\end{array}$ & & $\begin{array}{l}65.7( \pm \\
14.9)\end{array}$ & \\
\hline Number of AVF days/AVF (mean. \pm SD) & $\begin{array}{l}746( \pm \\
532)\end{array}$ & & $\begin{array}{l}723( \pm \\
544)\end{array}$ & & $\begin{array}{l}867( \pm \\
534)\end{array}$ & & $\begin{array}{l}623( \pm \\
413)\end{array}$ & & $\begin{array}{l}524( \pm \\
504)\end{array}$ & \\
\hline Number of AVF days (number. \%) & 990,405 & 100 & 530,322 & 54 & 332,944 & 34 & 104,041 & 11 & 23,098 & 2 \\
\hline $\begin{array}{l}\text { Number of AVFs using the technique } \\
\text { (number. \%) }\end{array}$ & 1328 & 100 & 733 & 55 & 384 & 29 & 167 & 13 & 44 & 3 \\
\hline
\end{tabular}

Abbreviations: SD Standard Deviation, $B H s$ Buttonhole sharp, $B H b$ Buttonhole blunt, $R L$ Ropeladder, AP Area puncture

to AVF and cannulation technique. They reported a trend towards an increased infection rate when using the $\mathrm{BH}$ technique $[18,20]$. However, the studies included in these reviews were relatively small and differed in the duration of follow-up and hygiene routines, such as the type of disinfectant used, when disinfection was performed in relation to removal of the scab, and how the scab was removed [25-27].

The number of AVF-related infections in this study were low compared to previous studies [15, 26, 28]. When comparing our study to the frequency reported by a study from Belgium [29], the infection rate was in rough agreement regardless of cannulation technique.

What could be suspected is that not all AVF infections are registered. However, the low infection rate in our study is in line with the frequency of AVF infections found in a review of medical records from southern Sweden [12]. The low number of total infections in the Swedish dialysis population also corresponds well with the low total mortality rate due to infections. In Sweden, the total infection-related mortality among patients in need of dialysis is 3\% [30]. A study from the Netherlands, Canada, Norway, Spain, France, and Turkey reported a total infection mortality rate of $6 \%$ in the dialysis population [31], and a Danish study reported a total infection mortality rate of $4.1 \%$ [32]. The occurrence of interventions due to stenosis [33] and hemorrhage [28] also seems to be in the same magnitude as in previous studies, therefore

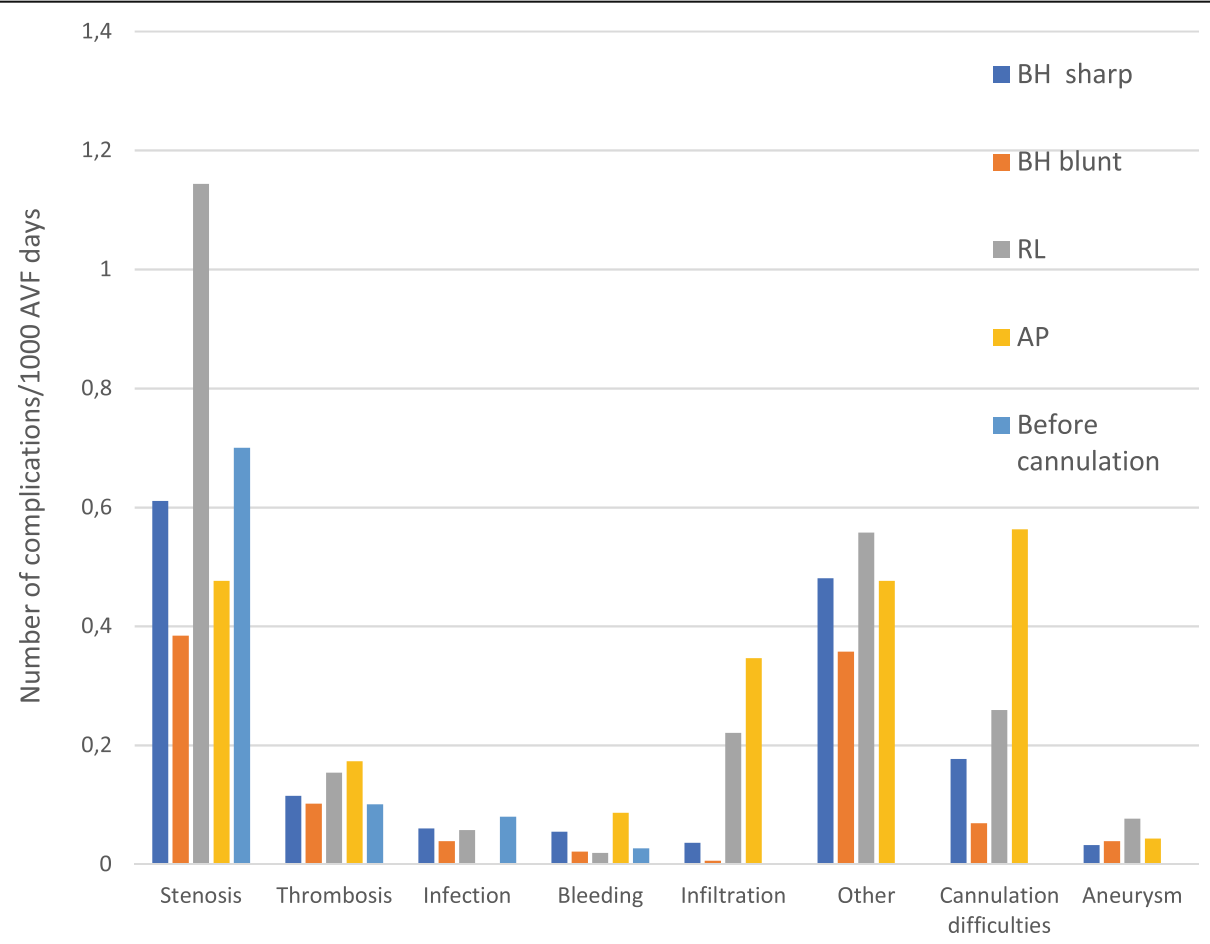

Fig. 2 Number of complications per 1000 AVF-days for different cannulation techniques according to AVF complication. Before cannulation is the time from the creation of the AVF until the cannulation began 
Table 4 Comparisons and statistical analysis of the number of complications with the different cannulation techniques

\begin{tabular}{|c|c|c|c|c|c|c|c|}
\hline$n=1328$ & $\begin{array}{l}\text { No of complic. /1000 AVF } \\
\text { days }\end{array}$ & $95 \% \mathrm{Cl}$ & $\begin{array}{l}\text { No of complic /1000 AVF } \\
\text { days }\end{array}$ & $95 \% \mathrm{Cl}$ & IRR & $95 \% \mathrm{Cl}$ & $P$ value \\
\hline & $\mathrm{BHs}$ & & $\mathrm{BHb}$ & & & & \\
\hline Stenosis & 0.61 & 0.55 to 0.68 & 0.38 & 0.32 to 0.46 & 1.59 & 1.29 to 1.97 & $\begin{array}{l}< \\
0.001\end{array}$ \\
\hline Thrombosis & 0.12 & 0.09 to 0.15 & 0.10 & 0.07 to 0.14 & 1.13 & 0.73 to 1.77 & 0.58 \\
\hline Infection & 0.06 & 0.04 to 0.09 & 0.04 & 0.02 to 0.07 & 1.55 & 0.79 to 3.21 & 0.18 \\
\hline Bleeding & 0.05 & 0.04 to 0.08 & 0.02 & 0.01 to 0.04 & 2.60 & 1.12 to 7.03 & 0.02 \\
\hline Infiltration & 0.04 & 0.02 to 0.06 & 0.01 & 0.001 to 0.02 & 5.96 & 1.44 to 52.81 & 0.01 \\
\hline Other & 0.48 & 0.42 to 0.54 & 0.36 & 0.3 to 0.43 & 1.35 & 1.08 to 1.69 & 0.01 \\
\hline $\begin{array}{l}\text { Cannulation } \\
\text { difficulty }\end{array}$ & 0.18 & 0.14 to 0.22 & 0.07 & 0.04 to 0.1 & 2.57 & 1.61 to 4.24 & $\begin{array}{l}< \\
0.001\end{array}$ \\
\hline \multirow[t]{2}{*}{ Aneurysm } & 0.03 & 0.02 to 0.05 & 0.04 & 0.02 to 0.07 & 0.82 & 0.38 to 1.84 & 0.59 \\
\hline & BHs & & $\mathbf{R L}$ & & & & \\
\hline Stenosis & 0.61 & 0.55 to 0.68 & 1.14 & 0.95 to 1.37 & 0.53 & 0.43 to 0.66 & $\begin{array}{l}< \\
0.001\end{array}$ \\
\hline Thrombosis & 0.12 & 0.09 to 0.15 & 0.15 & 0.09 to 0.25 & 0.75 & 0.43 to 1.39 & 0.30 \\
\hline Infection & 0.06 & 0.04 to 0.09 & 0.06 & 0.02 to 0.13 & 1.05 & 0.43 to 3.06 & 0.92 \\
\hline Bleeding & 0.05 & 0.04 to 0.08 & 0.02 & 0.002 to 0.07 & 2.84 & 0.72 to 24.60 & 0.13 \\
\hline Infiltration & 0.04 & 0.02 to 0.06 & 0.22 & 0.14 to 0.33 & 0.16 & 0.08 to 0.31 & $\begin{array}{l}< \\
0.001\end{array}$ \\
\hline Other & 0.48 & 0.42 to 0.54 & 0.56 & 0.42 to 0.72 & 0.86 & 0.65 to 1.17 & 0.31 \\
\hline $\begin{array}{l}\text { Cannulation } \\
\text { difficulty }\end{array}$ & 0.18 & 0.14 to 0.22 & 0.26 & 0.17 to 0.38 & 0.68 & 0.44 to 1.09 & 0.08 \\
\hline \multirow[t]{2}{*}{ Aneurysm } & 0.03 & 0.02 to 0.05 & 0.08 & 0.03 to 0.15 & 0.42 & 0.17 to 1.12 & 0.04 \\
\hline & $\mathrm{BHs}$ & & AP & & & & \\
\hline Stenosis & 0.61 & 0.55 to 0.68 & 0.48 & 0.24 to 0.85 & 1.29 & 0.71 to 2.60 & 0.41 \\
\hline Thrombosis & 0.12 & 0.09 to 0.15 & 0.17 & 0.05 to 0.44 & 0.66 & 0.25 to 2.52 & 0.42 \\
\hline Infection & 0.06 & 0.04 to 0.09 & 0 & 0 to 0.2 & - & - & 0.24 \\
\hline Bleeding & 0.05 & 0.04 to 0.08 & 0.09 & 0.01 to 0.31 & 0.63 & 0.16 to 5.46 & 0.53 \\
\hline Infiltration & 0.04 & 0.02 to 0.06 & 0.35 & 0.15 to 0.68 & 0.10 & 0.04 to 0.27 & $\begin{array}{l}< \\
0.001\end{array}$ \\
\hline Other & 0.48 & 0.42 to 0.54 & 0.48 & 0.24 to 0.85 & 1.01 & 0.55 to 2.05 & 0.98 \\
\hline $\begin{array}{l}\text { Cannulation } \\
\text { difficulty }\end{array}$ & 0.18 & 0.14 to 0.22 & 0.56 & 0.3 to 0.96 & 0.31 & 0.18 to 0.61 & $\begin{array}{l}< \\
0.001\end{array}$ \\
\hline \multirow[t]{2}{*}{ Aneurysm } & 0.03 & 0.02 to 0.05 & 0.04 & 0.001 to 0.24 & 0.74 & 0.12 to 30.94 & 0.77 \\
\hline & $\mathrm{BHb}$ & & $\mathrm{RL}$ & & & & \\
\hline Stenosis & 0.38 & 0.32 to 0.46 & 1.14 & 0.95 to 1.37 & 0.34 & 0.26 to 0.44 & $\begin{array}{l}< \\
0.001\end{array}$ \\
\hline Thrombosis & 0.10 & 0.07 to 0.14 & 0.15 & 0.09 to 0.25 & 0.66 & 0.36 to 1.29 & 0.17 \\
\hline Infection & 0.04 & 0.02 to 0.07 & 0.06 & 0.02 to 0.13 & 0.68 & 0.24 to 2.17 & 0.43 \\
\hline Bleeding & 0.02 & 0.01 to 0.04 & 0.02 & 0.002 to 0.07 & 1.09 & 0.21 to 10.79 & 0.91 \\
\hline Infiltration & 0.01 & $\begin{array}{l}0.001 \text { to } \\
0.02\end{array}$ & 0.22 & 0.14 to 0.33 & 0.03 & 0.003 to 0.11 & $\begin{array}{l}< \\
0.001\end{array}$ \\
\hline Other & 0.36 & 0.3 to 0.43 & 0.56 & 0.42 to 0.72 & 0.64 & 0.46 to 0.89 & 0.01 \\
\hline $\begin{array}{l}\text { Cannulation } \\
\text { difficulty }\end{array}$ & 0.07 & 0.04 to 0.1 & 0.26 & 0.17 to 0.38 & 0.27 & 0.15 to 0.48 & $\begin{array}{l}< \\
0.001\end{array}$ \\
\hline \multirow[t]{2}{*}{ Aneurysm } & 0.04 & 0.02 to 0.07 & 0.08 & 0.03 to 0.15 & 0.51 & 0.20 to 1.41 & 0.12 \\
\hline & $\mathrm{AP}$ & & $\mathrm{BHb}$ & & & & \\
\hline
\end{tabular}


Table 4 Comparisons and statistical analysis of the number of complications with the different cannulation techniques (Continued)

\begin{tabular}{|c|c|c|c|c|c|c|c|}
\hline$n=1328$ & $\begin{array}{l}\text { No of complic. /1000 AVF } \\
\text { days }\end{array}$ & $95 \% \mathrm{Cl}$ & $\begin{array}{l}\text { No of complic /1000 AVF } \\
\text { days }\end{array}$ & $95 \% \mathrm{Cl}$ & IRR & $95 \% \mathrm{Cl}$ & $P$ value \\
\hline Stenosis & 0.48 & 0.24 to 0.85 & 0.38 & 0.32 to 0.46 & 1.24 & 0.60 to 2.29 & 0.49 \\
\hline Thrombosis & 0.17 & 0.05 to 0.44 & 0.10 & 0.07 to 0.14 & 1.70 & 0.44 to 4.75 & 0.31 \\
\hline Infection & 0 & 0 to 0.2 & 0.04 & 0.02 to 0.07 & 0.00 & 0.00 to 4.73 & 0.34 \\
\hline Bleeding & 0.09 & 0.01 to 0.31 & 0.02 & 0.01 to 0.04 & 4.12 & 0.42 to 21.63 & 0.06 \\
\hline Infiltration & 0.35 & 0.15 to 0.68 & 0.01 & $\begin{array}{l}0.001 \text { to } \\
0.02\end{array}$ & 57.66 & $\begin{array}{l}11.51 \text { to } \\
557.34\end{array}$ & $\begin{array}{l}< \\
0.001\end{array}$ \\
\hline Other & 0.48 & 0.24 to 0.85 & 0.36 & 0.3 to 0.43 & 1.33 & 0.65 to 2.47 & 0.36 \\
\hline $\begin{array}{l}\text { Cannulation } \\
\text { difficulty }\end{array}$ & 0.56 & 0.3 to 0.96 & 0.07 & 0.04 to 0.1 & 8.15 & 3.79 to 16.77 & $<0.001$ \\
\hline \multirow[t]{2}{*}{ Aneurysm } & 0.04 & 0.001 to 0.24 & 0.04 & 0.02 to 0.07 & 1.11 & 0.03 to 7.38 & 0.92 \\
\hline & AP & & RL & & & & \\
\hline Stenosis & 0.48 & 0.24 to 0.85 & 1.14 & 0.95 to 1.37 & 0.42 & 0.20 to 0.77 & 0.004 \\
\hline Thrombosis & 0.17 & 0.05 to 0.44 & 0.15 & 0.09 to 0.25 & 1.13 & 0.27 to 3.49 & 0.83 \\
\hline Infection & 0 & 0 to 0.2 & 0.06 & 0.02 to 0.13 & 0.00 & 0.00 to 3.83 & 0.25 \\
\hline Bleeding & 0.09 & 0.01 to 0.31 & 0.02 & 0.002 to 0.07 & 4.50 & 0.33 to 62.14 & 0.10 \\
\hline Infiltration & 0.35 & 0.15 to 0.68 & 0.22 & 0.14 to 0.33 & 1.57 & 0.61 to 3.63 & 0.27 \\
\hline Other & 0.48 & 0.24 to 0.85 & 0.56 & 0.42 to 0.72 & 0.85 & 0.40 to 1.64 & 0.63 \\
\hline $\begin{array}{l}\text { Cannulation } \\
\text { difficulty }\end{array}$ & 0.56 & 0.3 to 0.96 & 0.26 & 0.17 to 0.38 & 2.17 & 1.03 to 4.35 & 0.02 \\
\hline Aneurysm & 0.04 & 0.001 to 0.24 & 0.08 & 0.03 to 0.15 & 0.56 & 0.01 to 4.20 & 0.58 \\
\hline
\end{tabular}

As the significance level is adjusted only $p$-values $<0.008$ are bold. Abbreviation: $C I$ Confidence interval, IRR Incidence risk ratio, $C l$ Confidence interval, IRR Incidence risk ratio, $B H s$ Buttonhole sharp, $B H b$ Buttonhole blunt, RL Rope ladder, $A P$ Area puncture

we assume that the incidence of infections also has been reported to the same extent.

Studies have previously reported that strict adherence to the hygiene routines is important when $\mathrm{BH}$ is used $[28,34]$. The low rate of AVF infections in this study may depend on well-established hygiene protocols and good adherence to these routines in the studied population. It may also be easier to remember performing all of the steps in the hygiene protocol if the majority of patients are cannulated using the $\mathrm{BH}$ technique compared to if only a few in the unit use this technique. Previous studies indicate that compliance with hygiene routines can easily fail [34, 35].

This study indicates that diabetes slightly increased (not significant) the risk of AVF-related infections. Right-sided AVF also emerged as a factor that perhaps increased the risk of AVF infection in BHs. The reason is unclear. It may be more difficult to wash the dominant arm properly between dialysis sessions. Previous studies have demonstrated that skin bacteria, such as Staphylococcus aureus, cause the majority of AVF infections [15, 36]. If this is correct and poor hygiene on the dominant arm increases the risk of infections, then good personal hygiene is important for avoiding AVF-related infections. Kaplowitz et al. previously stated that the degree of personal hygiene affects the outcome of this type of infection [37]. As other complications also are more common in the AVFs in right arms (see Table S1) there might be a correlation between these complications and their interventions and the risk of AVF infections.

Even though this study did not find a significant difference in infection frequency between $\mathrm{RL}$ and $\mathrm{BH}$, other studies have reported such a difference $[15,28]$. This suggests that certain hygiene routines affect the frequency. However, as long as the cause of the increased infection rates is unknown, more research is warranted. Units using $\mathrm{BH}$ that have a low infection rate should continue to adhere to their hygiene routines but also register and evaluate their infection rates.

Regardless of cannulation technique, stenosis was the most common type of complication. This finding confirms the tendency in previous studies of BHb patients having fewer interventions for stenosis and thrombosis [18]. Stenosis is more common in patients who receive an AVF using $\mathrm{BH}$ technique and have diabetes (see Table S1). Stenosis is also more common among patients aged over 70 years using BHb, BHs and RL. Therefore, it is likely that the development of stenosis is generally more common in the elderly. It is important to have in mind that stenosis do have other risk factors than the choice of cannulation technique. 
Hemorrhages were not, more likely when AP was used. Perhaps this was a result of the small size of patients using this technique.

Previous studies have shown that the development of aneurysms and pseudoaneurysms is more likely using both AP and RL compared to BHb [34, 38]. This was not confirmed in this study. Notably, however, the only aneurysms/pseudoaneurysms that are registered are those requiring some kind of treatment. Untreated dilated AVFs will remain unrecorded, and the true incidence of aneurysm related to the cannulation technique will be left to future studies to explore.

Surprisingly, AP caused more cannulation difficulties than other techniques. AP is the most frequently used technique in Europe, as it causes few acute complications, such as infiltrations and cannulation difficulties, and is easy to use [10]. The cannulation difficulties in this study are not those that nurses and patients encounter in everyday life. Cannulation difficulties registered in the SRR lead to some kind of treatment. Therefore, it is likely that AP is chosen when the AVFs are small and thin in order to widen the AVF [38]. When the effect of this intervention fails, the AVF has to be treated with, for example, an angioplasty to prolong its patency.

Additional factors that affect the incidence of complications are older age, female gender, and having diabetes, which results in an increased risk of developing complications [12, 39]. In addition, in the initial group of 2601 AVF (see Fig. 1) s, patients who had one or more complications changed the cannulation technique several times. Therefore, the occurrence of a complication is likely to affect the choice of cannulation technique.

The different cannulation techniques affect the incidence of complications to varying degrees. Therefore, the choice of cannulation technique can result in an increased or decreased risk of complications. Guidelines primarily advocate RL because of the low risk of infections. According to the same guidelines, $\mathrm{BH}$ should only be used in those with a short cannulation segment $[1,2,40]$. The present study shows that it is possible to use $\mathrm{BH}$, as well as $\mathrm{RL}$, for a long period with an equivalent infection frequency. Therefore, it is reasonable to consider the increased risk of all types of complications when choosing a cannulation technique. Viecelli et al. found that both patients and health professionals think that a functioning AVF is the most important issue [41]. If it is possible to prevent stenosis, infiltrations and cannulation difficulties by choosing a particular cannulation technique, it is possible to reduce suffering from painful and timeconsuming complications and simultaneously reduce expensive interventions. This is also in line with the person-centred approach gaining ground in health care.

The present study has several limitations. First, as registration is done retrospectively and manually by participating dialysis units, there is uncertainty whether data are transmitted correctly. Another limitation is that several of the observed complications are difficult to define. Therefore, it is uncertain whether all complications that occurred were properly registered. It is also unclear what type of complications are hidden behind the category "other" in the SRR. Complications may be placed there instead of under the proper category. Several of the complications also have other confounding factors than those included in SRR, for example not registered everyday complications, direction of the needle or indications and routines for choosing one cannulation technique over the other.

Future studies in this field should examine how a cannulation technique is chosen for the individual patient. For example, is the choice of cannulation technique influenced by previous complications? It would also be valuable to investigate each cannulation technique in a prospective study to determine their impact on everyday complications, such as oozing, prolonged post-dialysis bleeding, and AVF maturation. Additional studies are also of interest regarding the optimal hygiene routine during cannulation. For example, does it matter what type of disinfectant is used and how it is applied?

\section{Conclusions}

The cannulation technique with the fewest complications in this study is BHb. BH cannulation does not necessarily increase the risk of AVF infection. Both BHs and $\mathrm{BHb}$ can be used with an incidence of infections in the same magnitude as RL and AP. Units that already have a low infection rate may continue using $\mathrm{BH}$. In this way, it is possible to reduce cannulation-related complications, increase quality of life for the patients, and decrease socio-economic burden on the healthcare organization.

\section{Abbreviations}

AP: Area puncture; AVF: Arteriovenous fistula; BH: Buttonhole; BHb: Buttonhole blunt; BHs: Buttonhole sharp; Cl: Confidence Interval; CKD: Chronic Kidney Disease; ESRD: End Stage Renal Disease; IRR: Incidence Rate Ratio; MH: Mantel-Haenszel; RL: Ropeladder; SD: Standard deviation; SRR: Swedish Renal Registry

\section{Supplementary Information}

The online version contains supplementary material available at https:/doi. org/10.1186/s12882-021-02458-z.

Additional file 1: Table S1. AVFs distributed by cannulation technique and subgroups by gender, side, diabetes status, and age. Table S2. Comparisons and statistical analysis of the number of complications with the different cannulation techniques. 


\section{Acknowledgments}

The authors thank Mats Fredriksson at Forum Östergötland and Johan Lyth at FoU unit Region Östergötland for statistical advice and support and Swedish Renal Registry and all participating hemodialysis units for access to the data.

\section{Authors' contributions}

Research idea and study design: KS, AF, FU; data acquisition: KS; data analysis/interpretation: KS, FU; statistical analysis: KS, FU; supervision/ mentorship: FU, AF. Each author contributed important intellectual content during manuscript drafting or revision, accepts personal accountability for the author's own contributions, and agrees to ensure that questions pertaining to the accuracy or integrity of any portion of the work are appropriately investigated and resolved. The author(s) read and approved the final manuscript.

\section{Funding}

KS received grants from Region Östergötland for the research. The funding source had no involvement in study design, conduct, writing the report, or the decision to submit the report for publication. Open Access funding provided by Linköping University.

\section{Availability of data and materials}

The data underlying this article cannot be shared publicly due to the privacy of individuals that participated in the study. The data are available from Swedish Renal Registry (SRR). Restrictions apply to the availability of these data, which were used under license for this study. Data are available at https://www.medscinet.net/snr/forskning.aspx with the permission of SRR.

\section{Declarations}

\section{Ethics approval and consent to participate}

The Swedish Ethical Review Authority (ref. 2019-02554) gave ethical approval. Swedish regulations require that patients shall be informed about participation in a registry by the clinic. Patients shall also be informed that they can choose not to participate in the registry. Informed consent is therefore not required.

\section{Consent for publication}

Not applicable.

\section{Competing interests}

The authors declare that they have no competing interests.

\section{Author details}

'Department of Nephrology and Department of Health, Medicine and Caring Sciences, Linköping University, SE-581 85 Linköping, Sweden. ${ }^{2}$ Department of Health Technologies, Tallinn University of Technology, Tallinn, Estonia.

Received: 9 January 2021 Accepted: 22 June 2021

Published online: 07 July 2021

\section{References}

1. Lok CE, Huber TS, Lee T, Shenoy S, Yevzlin AS, Abreo K, et al. kdoqi clinical practice guideline for vascular access: 2019 Update. Am J Kidney Dis. 2020; 75(4):S1-S164. https://doi.org/10.1053/j.ajkd.2019.12.001

2. Schmidli J, Widmer MK, Basile C, de Donato G, Gallieni M, Gibbons CP, et al. Editor's choice - vascular access: 2018 clinical practice guidelines of the European Society for Vascular Surgery (ESVS). Eur J Vasc Endovasc Surg. 2018;55(6):757-818. https://doi.org/10.1016/j.ejvs.2018.02.001.

3. Ravani P, Quinn R, Oliver M, Robinson B, Pisoni R, Pannu N, et al. Examining the association between hemodialysis access type and mortality: the role of access complications. Clin J Am Soc Nephrol. 2017;12(6):955-64. https://doi. org/10.2215/cjn.12181116.

4. Elseviers MM, Van Waeleghem J-P, European D. Transplant nurses association/European renal care a. identifying vascular access complications among ESRD patients in Europe. A prospective, multicenter study. Nephrol News Issues. 2003;17(8):61-99.

5. Parisotto MT, Pancirova J. Vascular access Cannulation and care A nursing best practice guide for arteriovenous fistula. Lucerne European Dialysis and
Transplant Nurse Association/European Renal Care Association (EDTNA/ ERCA); 2014.

6. Casey JR, Hanson CS, Winkelmayer WC, Craig JC, Palmer S, Strippoli GF, et al Patients' perspectives on hemodialysis vascular access: a systematic review of qualitative studies. Am J Kidney Dis. 2014;64(6):937-53. https://doi.org/1 0.1053/j.ajkd.2014.06.024.

7. Besarab A, Kumbar L. Vascular access cannulation practices and outcomes. Kidney Int. 2014;86(4):671-3. https://doi.org/10.1038/ki.2014.158.

8. van Loon M, Kessel AGH, van der Sande FM, Tordoir JHM. Cannulation practice pattern in haemodialysis vascular access: predictors for unsuccessful cannulation. J Renal Care. 2009;35(2):82-9. https://doi.org/10.1111/j.17556686.2009.00092.x.

9. Parisotto MT, Schoder VU, Miriunis C, Grassmann AH, Scatizzi LP, Kaufmann $P$, et al. Cannulation technique influences arteriovenous fistula and graft survival. Kidney Int. 2014;86(4):790-7. https://doi.org/10.1038/ki.2014.96.

10. Parisotto MT, Pelliccia F, Grassmann A, Marcelli D. Elements of dialysis nursing practice associated with successful cannulation: result of an international survey. J Vasc Access. 2017;18(2):114-9. https://doi.org/10.5301/ jva.5000617.

11. Rayner HC, Pisoni RL, Gillespie BW, Goodkin DA, Akiba T, Akizawa T, et al. Creation, cannulation and survival of arteriovenous fistulae: data from the Dialysis outcomes and practice patterns study. Kidney Int. 2003;63(1):323-30. https://doi.org/10.1046/j.1523-1755.2003.00724.x.

12. Staaf K, Uhlin F. Cannulation with sharp or blunt needles for haemodialysis: the importance of cannulation technique for the patient's lifeline. J Vasc Access. 2019;20(2):161-8. https://doi.org/10.1177/1129729818788811.

13. Verhallen AM, Kooistra MP, van Jaarsveld BC. Cannulating in haemodialysis: rope-ladder or buttonhole technique? Nephrol Dial Transplant. 2007;22(9): 2601-4. https://doi.org/10.1093/ndt/gfm043.

14. Morselli C, Chiari P, Aliberti T, Celli G, Catalani S, Miale I, et al. Sharp versus blunt needle use with buttonhole method: open randomised trail. J Ren Care. 2015;41(4):213-21. https://doi.org/10.1111/jorc.12119.

15. Lyman M, Nguyen DB, Shugart A, Gruhler H, Lines C, Patel PR. Risk of vascular access infection associated with buttonhole cannulation of fistulas: data from the National Healthcare Safety Network. Am J Kidney Dis. 2020; 76(1):82-9. https://doi.org/10.1053/j.ajkd.2019.11.006.

16. Almehmi A, Wang S. Partial aneurysmectomy is effective in managing aneurysm-associated complications of arteriovenous fistulae for hemodialysis: case series and literature review. Semin Dial: Wiley Online Library; 2012.

17. Jaffers GJ, Fasola CG. Experience with ulcerated, bleeding autologous dialysis fistulas. J Vasc Access. 2012;13(1):55-60. https://doi.org/10.5301/jva. 5000001.

18. Wong B, Muneer M, Wiebe N, Storie D, Shurraw S, Pannu N, et al. Buttonhole versus rope-ladder cannulation of arteriovenous fistulas for hemodialysis: a systematic review. Am J Kidney Dis. 2014;64(6):918-36. https://doi.org/10.1053/j.ajkd.2014.06.018.

19. Gallieni M, Hollenbeck M, Inston N, Kumwenda M, Powell S, Tordoir J, et al. Clinical practice guideline on peri- and postoperative care of arteriovenous fistulas and grafts for haemodialysis in adults. Nephrol Dial Transplant. 2019; 35(10):1824. https://doi.org/10.1093/ndt/gfz153.

20. Grudzinski A, Mendelssohn D, Pierratos A, Nesrallah G. A systematic review of buttonhole cannulation practices and outcomes. Semin Dial. 2013;26(4): 465-75. https://doi.org/10.1111/sdi.12116.

21. Stendahl M. Svenskt Njurregister: Årsrapport 2015: Svenskt njurregister; 2016

22. Sahai $H$, Khurshid A. Statistics in epidemiology: methods, techniques and applications: CRC press; 1995.

23. Njurregister S. Svenskt njurregister årsrapport 2020. Hämtad 2021-02-12 från: https://www.medscinet.net/snr/rapporter.aspx; 2020.

24. Welander G, Sigvant B. Validating vascular access data in the Swedish renal registry SRR. J Vasc Access. 2020;1129729820954737:112972982095473. https://doi.org/10.1177/1129729820954737.

25. MacRae JM, Ahmed SB, Hemmelgarn BR. Arteriovenous fistula survival and needling technique: long-term results from a randomized buttonhole trial. Am J Kidney Dis. 2014;63(4):636-42. https://doi.org/10.1053/j.ajkd.2013.09.015.

26. Chow J, Rayment G, San Miguel S, Gilbert M. A randomised controlled trial of buttonhole cannulation for the prevention of fistula access complications. J Ren Care. 2011;37(2):85-93. https://doi.org/10.1111/j.17556686.2011.00211.x

27. Castro MC, Silva Cde F, Souza JM, Assis MC, Aoki MV, Xagoraris M, et al. Arteriovenous fistula cannulation by buttonhole technique using dull 
needle. J Bras Nefrol. 2010;32(3):281-5. https://doi.org/10.1590/S0101-28002 010000300010.

28. Labriola L, Crott R, Desmet C, André G, Jadoul M. Infectious complications following conversion to buttonhole cannulation of native arteriovenous fistulas: a quality improvement report. Am J Kidney Dis. 2011;57(3):442-8. https://doi.org/10.1053/j.jajkd.2010.10.045.

29. Béchade C, Goovaerts T, Cougnet P, Labriola L, Jadoul M, Goffin E. Buttonhole cannulation is not associated with more AVF infections in a lowcare satellite dialysis unit: a long-term longitudinal study. PLoS One. 2015; 10(11):e0142256. https://doi.org/10.1371/journal.pone.0142256.

30. Njurregister S. Svenskt njurregister årsrapport 2019. Hämtad 2020-03-25 från: https://www.medscinet.net/snr/rapporter.aspx; 2020.

31. Peters SAE, Bots ML, Canaud B, Davenport A, Grooteman MPC, Kircelli F, et al. Haemodiafiltration and mortality in end-stage kidney disease patients: a pooled individual participant data analysis from four randomized controlled trials. Nephrol Dial Transplant. 2015;31(6):978-84. https://doi.org/1 0.1093/ndt/gfv349.

32. Chaudry MS, Gislason GH, Kamper A-L, Rix M, Larsen AR, Petersen A, et al. Increased risk of Staphylococcus aureus bacteremia in hemodialysis-a nationwide study. Hemodial Int. 2019;23(2):230-8. https://doi.org/10.1111/ hdi.12728.

33. Vaux E, King J, Lloyd S, Moore J, Bailey L, Reading I, et al. Effect of buttonhole cannulation with a polycarbonate PEG on in-center hemodialysis fistula outcomes: a randomized controlled trial. Am J Kidney Dis. 2013;62(1):81-8. https://doi.org/10.1053/j.ajkd.2013.01.011.

34. van Loon MM, Goovaerts T, Kessels AGH, van der Sande FM, Tordoir JHM. Buttonhole needling of haemodialysis arteriovenous fistulae results in less complications and interventions compared to the rope-ladder technique. Nephrol Dial Transplant. 2010;25(1):225-30. https://doi.org/10.1093/ndt/ gfp420.

35. Trépanier P, Quach C, Gonzales M, Fortin E, Kaouache M, Desmeules S, et al. Survey of infection control practices in hemodialysis units: preventing vascular access-associated bloodstream infections. Infect Control Hosp Epidemiol. 2014;35(7):833-8. https://doi.org/10.1086/676862

36. Christensen LD, Skadborg M-B, Mortensen AH, Mortensen C, Møller JK, Lemming $L$, et al. Bacteriology of the buttonhole cannulation tract in hemodialysis patients: a prospective cohort study. Am J Kidney Dis. 2018; 72(2):234-42. https://doi.org/10.1053/j.jajkd.2018.01.055.

37. Kaplowitz LG, Comstock JA, Landwehr DM, Dalton HP, Mayhall CG. Prospective study of microbial colonization of the nose and skin and infection of the vascular access site in hemodialysis patients. J Clin Microbiol. 1988;26(7):125762. https://doi.org/10.1128/jcm.26.7.1257-1262.1988.

38. Krönung G. Plastic deformation of Cimino fistula by repeated puncture. Dial Transplant. 1984;13(10):635-8

39. van Loon MM, Kessels AGH, van der Sande FM, Tordoir JHM. Cannulation practice patterns in haemodialysis vascular access: predictors for unsuccessful cannulation. J Ren Care. 2009;35(2):82-9. https://doi.org/1 0.1111/j.1755-6686.2009.00092.x.

40. Vale E, Lopez-Vargas P, Polkinghorne K. Nursing care of arteriovenous fistula/arteriovenous graft. Johan Briggs Inst Viitat. 2011:20:2014-37.

41. Viecelli AK, Howell M, Tong A, Teixeira-Pinto A, O'Lone E, Ju A, et al. Identifying critically important vascular access outcomes for trials in haemodialysis: an international survey with patients, caregivers and health professionals. Nephrol Dial Transplant. 2020;35(4):657-68. https://doi.org/1 0.1093/ndt/gfz148

\section{Publisher's Note}

Springer Nature remains neutral with regard to jurisdictional claims in published maps and institutional affiliations.

Ready to submit your research? Choose BMC and benefit from:

- fast, convenient online submission

- thorough peer review by experienced researchers in your field

- rapid publication on acceptance

- support for research data, including large and complex data types

- gold Open Access which fosters wider collaboration and increased citations

- maximum visibility for your research: over $100 \mathrm{M}$ website views per year

At BMC, research is always in progress.

Learn more biomedcentral.com/submissions 